\title{
The Hovey Group of Northeastern Maine
}

By LOUIS PAVLIDES

CONTRIBUTIONS TO STRATIGRAPHY

GE OLOG I A L SURVEY B ULL E T I N 1194-B

Defines stratigraphic nomenclature for some early Paleozoic rocks in northeast Maine 


\title{
UNITED STATES DEPARTMENT OF THE INTERIOR STEWART L. UDALL, Secretary
}

\author{
GEOLOGIGAL SURVEY
}

Thomas B. Nolan, Director

The U.S. Geological Survey Library has cataloged this publication as follows:

\section{Pavlides, Louis, 1921-}

The Hovey Group of northeastern Maine. Washington, U.S. Govt. Print. Off., 1964.

iii, 6 p. map, diagr. $24 \mathrm{~cm}$. (U.S. Geological Survey. Bulletin 1194-B) Contributions to stratigraphy.

1. Geology, Stratigraphic-Paleozoic. 2. Geólogy-Maine-Aroostook Co. 3. Geology-Nomenclature. I. Title. (Series) 


\section{CONTENTS}

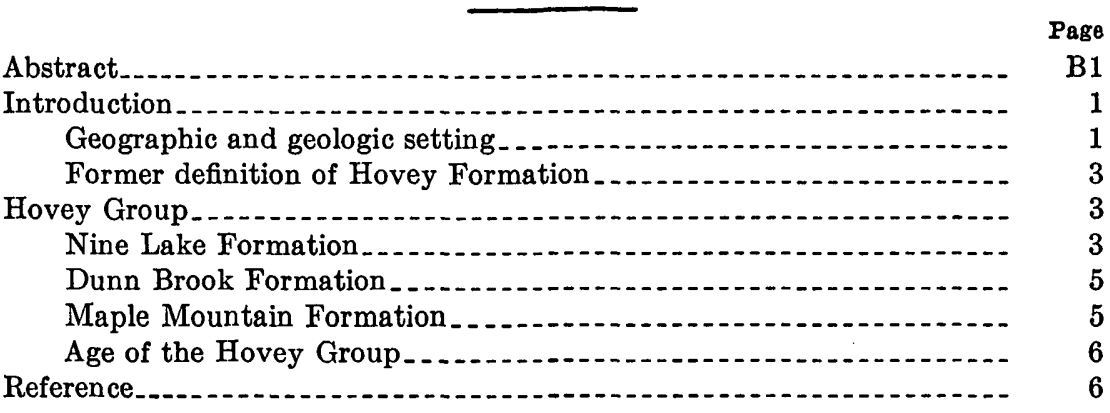

\section{ILLUSTRATIONS}

2. Generalized stratigraphic columns of the Hovey Formation of former usage and of the Hovey Group of this report....... 



\title{
CONTRIBUTIONS TO STRATIGRAPHY
}

\section{THE HOVEY GROUP OF NORTHEASTERN MAINE}

\author{
By Louts Pavlides
}

\section{ABSTRACT}

The Hovey Group, formerly the Hovey Formation, consists of the conformable Nine Lake, Dunn Brook, and Maple Mountain Formations that compose a eugeosynclinal suite of rocks about 22,000 feet thick in northeast Maine. The Nine Lake and Dunn Brook Formations are Ordovician or Silurian in age or both, and the Maple Mountain Formation is Silurian in age.

\section{INTRODUCTION}

A eugeosynclinal suite of rocks was named the Hovey Formation from mapping carried out in a fairly small region within the Howe Brook quadrangle in eastern Aroostook County, Maine (Pavlides, 1962, p. 12-21, fig. 3, pl. 1). Additional mapping in contiguous areas, reexamination of parts of the previously mapped terrane, and the discovery of additional fossils from within the Howe Brook quadrangle (fig. 1) now enable the rocks formerly assigned to the Hovey Formation to be more closely subdivided. The Hovey Formation is herein redefined as the Hovey Group-after Hovey Mountain in the Howe Brook quadrangle, Maine, the original type locality for the Hovey Formation (Pavlides, 1962, pl. 1). Rocks formerly considered as belonging to the upper and lower parts of the Hovey Formation or as members of it are therefore assigned formational rank.

\section{GEOGRAPHIC AND GEOLOGIC SETTING}

The stratigraphic subdivision herein presented results in large part from bedrock information not previously available in the Howe Brook quadrangle. Northern Maine is covered by glacial drift, and much of the region is heavily wooded. When the region was mapped in 1952 and 1953 (Pavlides, 1962, pl. 1), natural outcrops were few. Recent scraping by bulldozers, chiefly in building access hauling roads for pulp and lumber-cutting operations within the Howe Brook quadrangle, has made numerous new bedrock exposures. These new bedrock 


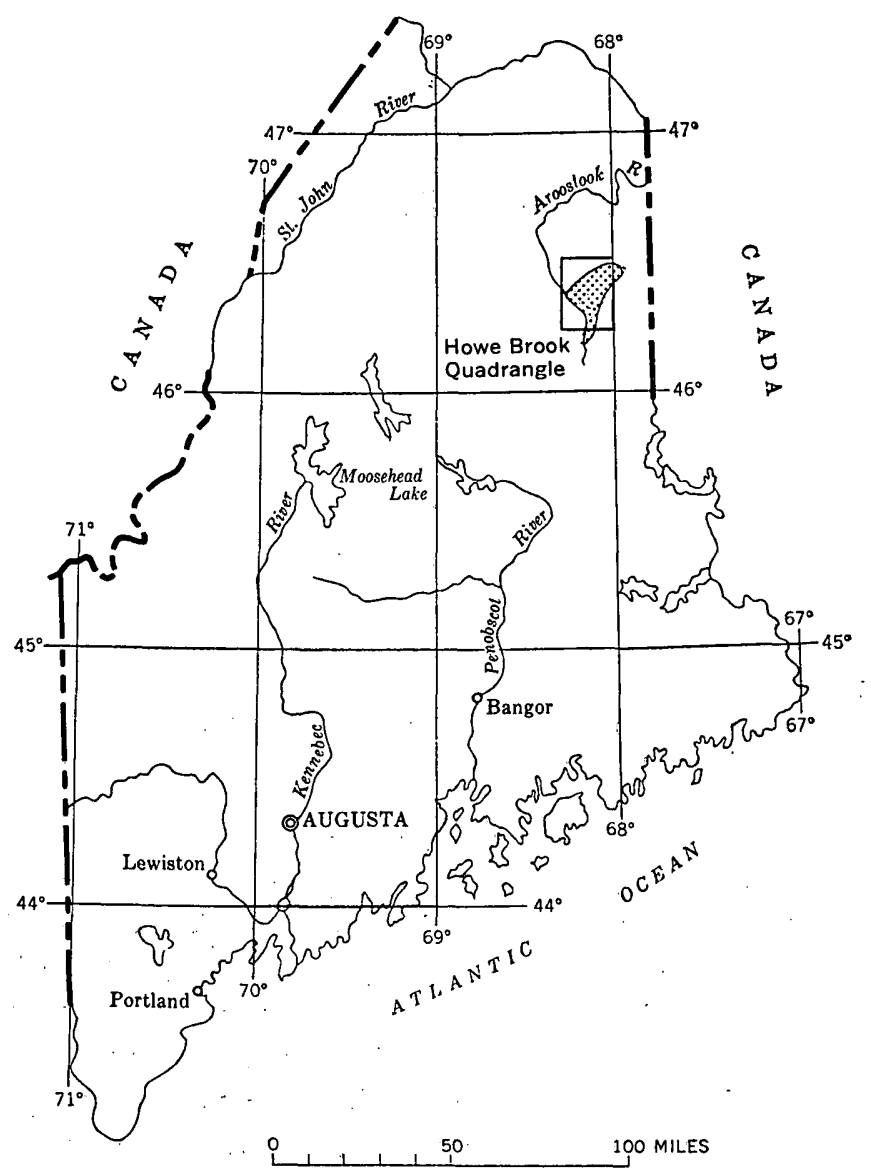

Figure 1.-Index map of Maine showing location of the Howe Brook quadrangle and the area (shaded) underlain by the Hovey Group.

exposures became available both in the area previously mapped (Pavlides, 1962) and in many other parts of the Howe Brook quadrangle. Thus, additional mapping in the region has resulted in more closely defining the extent of previously recognized stratigraphic units as well as permitting a more detailed subdivision of them.

Even with the new bedrock exposures, sections in the region are still not adequate to enable a detailed lithologic description to be made of the Hovey Group. Hence the lithologic descriptions given are composites from partial stratigraphic sections in different parts of the region. The thicknesses assigned to the different formations are estimates based on cross sections constructed across various parts of the area. Because the rocks are highly folded and broken by faults (Pavlides, 1962), the estimated thicknesses should only be considered as 
orders of magnitude. In general, the thicknesses assigned to the various formations of the Hovey Group are the same or only slightly different from those originally estimated for the various parts and members of the Hovey Formation from which they are defined.

\section{FORMER DEFINITION OF HOVEY FORMATION}

The Hovey Formation was described chiefly from bedrock exposures in the northeastern part of the Howe Brook quadrangle. As originally described (fig. $2 A$ ), the lower part of the Hovey Formation, about 8,000 feet thick, consists of gray-green and green slate interlayered with graywacke and conglomeratic graywacke. Locally it contains red and purple slate lenses and lentils of conglomeratic graywacke and metaperlite (Pavlides, 1962, p. 12-16). The upper part of the Hovey Formation, estimated to be about 7,000 feet thick, comprises $0-5,000$ feet of metavolcanic rocks of the Dunn Brook Member (Pavlides, 1962, p. 17-21) and 0-700 feet of volcanic breccia, including slate interbeds at its base (fig. $2 A$ ).

Sedimentary rocks as much as 6,000 feet thick overlie the Dunn Brook Member; they consist mostly of gray-green and green slate interbedded with lesser amounts of graywacke. Lenses of manganeseand iron-bearing rocks ranging in maximum thickness from 10 to 150 feet occur about 3,000-5,000 feet above the Dunn Brook Member (Pavlides, 1962, p. 21).

\section{HOVEY GROUP}

The Hovey Group as herein described consists of the Nine Lake, Dunn Brook, and Maple Mountain Formations.

\section{NINE LAKE FORMATION}

The lower part of the Hovey Formation is now named the Nine Lake Formation of the Hovey Group after Number Nine Lake near which the formation, in part, is exposed. Its thickness and lithologic features are those described above for the lower part of the Hovey Formation. It is now known, however, that the Saddleback Mountain Member (fig. $2 A$ ) is not the only unit of volcanic rocks in the formation, although the precise stratigraphic position of the other volcanic rocks is not known. It is also possible that the Saddleback Mountain Member (metaperlite) may occur at different stratigraphic levels rather than at just one level. The name Saddleback Mountain Member, which had been assigned to the metaperlitic rocks in the lower part of the Hovey Formation, is herein abandoned; and such volcanic rocks are considered to be un. named volcanic lenses of uncertain stratigraphic position within the Nine Lake Formation (fig. $2 B$ ). 


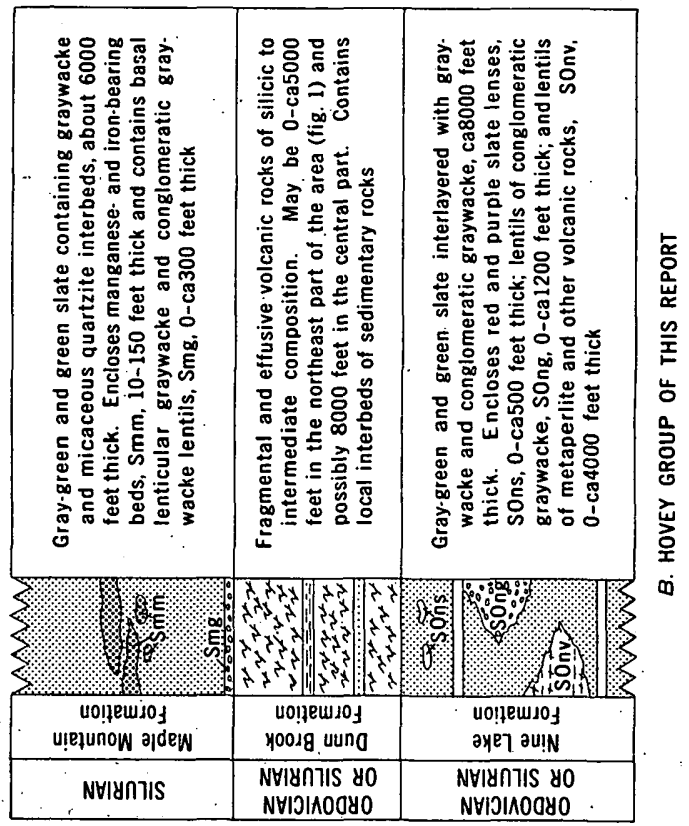

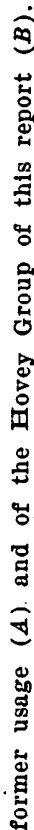

范

을.

总

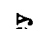

$\Xi$

芩

宽

d

范

ฐัّ

\begin{tabular}{|c|c|c|c|c|}
\hline \multicolumn{2}{|c|}{ 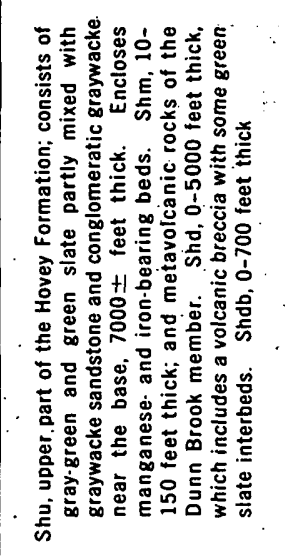 } & \multicolumn{2}{|c|}{ 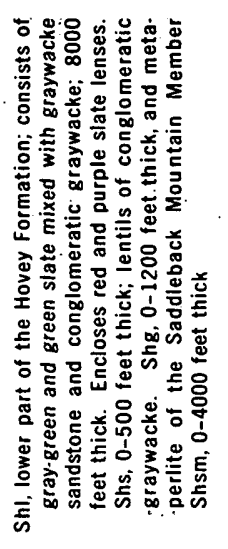 } & \\
\hline 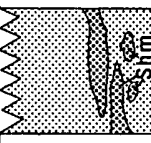 & 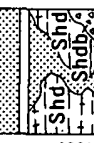 & Wo & $\begin{array}{l}10 \\
6 \\
6\end{array}$ & \\
\hline \multicolumn{4}{|c|}{ 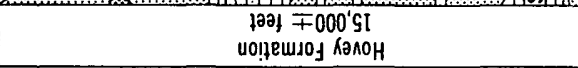 } & \\
\hline \multicolumn{4}{|c|}{ 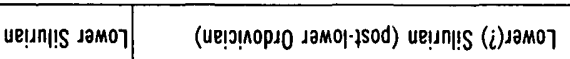 } & \\
\hline
\end{tabular}




\section{DUNN BROOK FORMATION}

The Dunn Brook Member of former usage (see fig. $2 A$ ) is here raised to the Dunn Brook Formation. As before, it contains metavolcanic rocks, including the volcanic breccia lentils. The Dunn Brook Formation is now known to extend to the west and southwest considerably beyond its previously mapped limits (Pavlides, 1962, pl. 1) and to underlie both the Maple Mountain Formation of Silurian age (see below) and rocks of Devonian age. It contains a wider variety of rocks than were originally assigned to it (Pavlides, 1962, p. 17-21). In addition to keratophyre, tuff, and volcanic breccia, considerable amounts of volcanic conglomerate and some metaperlite, pillow lavas, and other silicic and intermediate aphanitic and fine-grained volcanic rocks are now mapped in the Dunn Brook, together with a few slate and sandstone interbeds.

The thickness of the Dunn Brook is difficult to determine. Originally it was estimated to be mostly lenticular and as much as 5,000 feet thick; this thickness is still correct for the formation in the northeastern part of the Howe Brook quadrangle where it forms relatively small masses. In the central part of the Howe Brook quadrangle, its minimum thickness is at least 5,000 feet, and it may be as much as 8,000 feet thick or more.

\section{MAPLE MOUNTAIN FORMATION}

All the rocks stratigraphically above the Dunn Brook Formation are herein assigned to the Maple Mountain Formation, named for Maple Mountain in the Howe Brook quadrangle where a discontinuous section of part of this formation is exposed (Pavlides, 1962). The Maple Mountain Formation is estimated to be about 6,000 feet thick. Lenses of graywacke and conglomeratic graywacke of unknown thicknessprobably not more than several hundred feet thick-occur at the base of the Maple Mountain Formation. Above these basal clastic rocks is a sequence about 5,000 feet thick of gray-green and green slate containing sparser thin interbeds (1-3 ft thick) of graywacke and micaceous quartzite. Near the top of this sequence, approximately 5,000 feet stratigraphically above the base of the Maple Mountain Formation, are the lenticular manganese- and iron-bearing beds; these beds, which are 10-150 feet thick, were explored on Maple and Hovey Mountains and described in detail by Pavlides (1962). Ábout 1,000 feet of graygreen and green slate occurs above the manganese- and iron-bearing beds. Several thin volcanic ash beds $1 / 2-1$ inch thick occur within the iron and manganese deposits and in the slate overlying them. 


\section{AGE OF THE HOVEY GROUP}

The only fossils useful for dating some of the rocks assigned to the Hovey Group occur at a few places within the Maple Mountain Formation. Badly deformed brachiopods that occur in a basal graywacke bed in the Maple Mountain Formation (Pavlides, 1962, locality A of pl. 1) were previously dated as of Silurian or Early Devonian age by A. J. Boucot (Pavlides, 1962, p. 24). Through a great deal of painstaking effort on additional collections subsequently submitted to him, Boucot (written commun., 1962) identified the brachiopod Meristina, which indicates a Silurian age for this locality. Prof. O. M. B. Bulman (written commun., 1955) of the Sedgwick Museum in Cambridge, England, had earlier identified a pyritized Silurian graptolite from the Maple Mountain Formation (as herein defined) as Monograptus. This graptolite was found in a slate interbed in one of the lenticular manganese deposits (Pavlides, 1962, p. 23). Thus, the Maple Mountain Formation is of Silurian age, as determined from both the graptolite and the brachiopods found within it.

The underlying Dunn Brook Formation is not closely dated. At two places within the formation, a few crinoid columnals have been found which indicate that the unit is post-Cambrian in age and that it is at least in part of marine origin. It may be partially equivalent to the overlying Maple Mountain Formation, but it could be altogether older and of Ordovician age. In view of the available paleontologic and stratigraphic evidence, the Dunn Brook Formation is herein dated as of Ordovician or Silurian age or both.

The Nine Lake Formation also has not yielded fossils that allow it to be closely dated. At a few places, pelmatozoan debris including crinoid and cystoid framents were found, and a conglomerate bed in this formation contains bryozoans-probably trepostomes (Pavlides, 1962, table 4, see lower part of Hovey Formation). This fragmentary paleontologic evidence and the stratigraphic position of the Nine Lake Formation below the Dunn Brook Formation necessitates that it also be dated as of Ordovician or Silurian age or both, but older than the Dunn Brook Formation.

\section{REFERENCE}

Pavlides, Louis, 1962, Geology and manganese deposits of the Maple and Hovey Mountains area, Aroostook County, Maine: U.S. Geol. Survey Prof. Paper 362, 116 . p. 